\title{
To take or not to take the laptop or tablet to class, that is the question
}

Autores: Castillo-Manzano, José Ignacio; Castro Nuño, Mercedes; López Valpuesta, Lourdes; Sanz-Díaz, María Teresa; Yñiguez Ovando, Rocío

\section{Abstract}

In recent decades, so-called mobile learning or m-learning has become a new paradigm in education as a consequence of technological advances and the widespread use of mobile devices to access information and for communication. In this context, this paper analyzes different profiles depending on students' preferences for taking mobile devices (specifically tablets and/or laptops) to economics classes at the University of Seville (Spain). A survey-based field study of a sample of 412 students and the application of bivariate probit models show a low level of mobile device integration in teaching (devices taken to class by only $29.8 \%$ of respondents) with a slight predominance of laptops. The results also show differences between users of the two types of devices. Students who take their laptops to class usually live at home with their family, have already used them in pre-university levels, and are concerned about recharging their devices in class. However, although users who take their tablets to class also live with their parents, they are much more active on social network sites and more concerned about the quality of the internet connection. These findings enable the design of strategies to encourage students to attend class with their own mobile devices.

Keywords: university teaching, m-learning, mobile devices, bring your own device, educational technologies research, bivariate probit model.

JEL codes: A22, C35, C93, I20, O33.

\section{Introduction}

Meeting the needs of today's always-on-the-move society has led to the rapid development of information and communication technologies and the widespread use of technological advances, such as laptops, tablets and smartphones, connected with each other through networks and software (Alhassan, 2016; Zydney and Warner, 2016). As a result, a new social and educational paradigm has been shaped, with learning based on these types of mobile devices (so-called mobile learning or m-learning)becoming an indispensable educational tool at both pre-university (Kim, et al., 2016; Popović et al., 2016) and university level (Henríquez-Ritchie and Organista-Sandoval, 2012; Lin and Lin, 2016). Compared to the traditional concept of teaching, m-learning provides a more flexible, collaborative and spontaneous learning model, as proven by the numerous studies found in the scientific literature: both systematic reviews, such as Baran (2014), Cochrane (2014), Crompton et al, (2016), Peña-Ayala and Cárdenas 
(2016), Shuib et al., (2015), and Zydney and Warner (2016), and meta-analyses, such as Wu et al. (2012).

Online or electronic learning (e-learning) provides new opportunities for direct learning and improving student performance (see Wu et al., 2010 for a broader examination). $M$ learning can be regarded as a subset of the e-learning framework (Peters, 2007) or the progression or extension of e-learning (Althunibat, 2015), as it combines advances in information and communication technology by way of widely-used devices. M-learning can also be considered a step forward, as a greater number of potential users are involved (Jones et al, 2009; Gan and Balakrishnan, 2014) and, as Wu et al. (2012) state, learning with mobile devices can be done anywhere where there is a wifi connection. In general terms, following Jacob and Isaac (2008), this educational scenario can be defined as the point where the use of mobile computing/communication devices on the one hand, and e-learning on the other, intersect with each other.

In general, Information and Communication Technology-based (ICT) technological infrastructure not only drives innovation in learning, but, according to Wu et al. (2008) and Landers and Armstrong (2015), could also integrate everyone involved in e-learning processes or training and instructional contexts. For authors such as Alhassan (2016), using mobile technologies in learning can be regarded as the next great revolution in teaching, as there are more pros than cons. Their advantages can be grouped in three blocks. First, they have the potential to improve learning systems, as they encourage student participation (Castillo et al, 2016) and make it easier to take notes (Mosleh et al, 2016; Norman and Furnes, 2016); enhance direct student involvement (Cheung, 2008; Green, 2016; Jemni et al, 2016; Wongand Mak, 2016); enable the use of apps adapted to different subject matter (Domingo and Gargante, 2016; Jordano de la Torre et al, 2016); make it easy to instantly find information (Hassanet al., 2016; Holderied, 2016); and boost so-called mobile collaborative learning (Reychav and $\mathrm{Wu}, 2015$ ), i.e., integration between students and instructors (Alhassan, 2016).Second, among the technical advantages are their immediacy and portability (Peters, 2007; Zayimand Ozel, 2015),enabling the greater integration of Information Technologies (IT) in the classroom (Cook and Santos, 2016; Lin et al., 2016). Finally, m-learning has the advantage of improving personal and social involvement and integration by raising social interactivity (Peters, 2007) and enabling peer interaction and cooperation (Fisher and Bierd,2006).

Possible disadvantages to integrating these devices into teaching include: first, from the educational point of view, they can become a source of distraction in the classroom (Alhassan, 2016; Chen and Yan, 2016; Wilkinson and Barter, 2016)and it can even be a disadvantage for students to have access to too much information that they do not know how to handle (Alhassan, 2016);second, technical disadvantages, such as mobile devices' battery life, different operating systems that occasionally require different software, connection speed (Alhassan, 2016) and screen size and resolution (Vibergand Grönlund, 2013); and from the financial point of view, the cost has to be mentioned, as 
each individual student has to have a device to be able to participate (Popovic et al., 2016).

Education centers are taking a variety of business-type initiatives to mitigate economic disadvantages and boost the growing implementation of m-learning. One well-known initiative is Bring Your Own Device (BYOD), which consists of encouraging students to attend class with self-owned mobile devices with which they are familiar (Kong and Song, 2015; Song, 2016).Although until only a few years ago a student taking a cell phone or a laptop to class was regarded as a sign of a lack of attention or a source of external distraction, today BYOD is encouraged by a number of universities (Imazeki, 2014; Wang, 2015) and schools (Song,2014; 2016), as it enables students to access learning content.

This strategy has broad advantages in terms of cost reductions for its advocates (Zahadat et al., 2015), in this case universities, which no longer need IT rooms and computer labs (Kobus et al., 2013); however, the advantage could also become a disadvantage, as it evidences an income gap between students (see Kobus et al, 2013).

This possible disadvantage of the BYOD strategy has led to the implementation of the well-known One-to-One Laptop Programs (Nielsen et al., 2015). These consist of the educational establishments themselves providing an internet-connected laptop to each of their students. Programs of this type are usually directed at pre-university education, both Primary(as indicated in studies by Nielsen et al., 2015 for Australia; and Pereira and Pereira, 2015 for Portugal, among others); and Secondary (as analyzed in Howard et al., 2015, for example). Authors such as James (2015) have drawn attention to these programs' high cost when they are publicly financed, which makes them unsustainable in the long term, particularly in the case of developing countries.

The topic's complexity means that the impact of integrating mobile devices into the classroom can be evaluated from many different angles. Following Hwang and $\mathrm{Wu}$ (2014), more than half of the analyzed studies do not focus on the impact on student performance and learning, but assess other aspects, such as the various facets of student engagement (Witecki and Nonnecke, 2015); student perceptions of m-learning (Althunibat, 2015); students' opinions of being forced to take a device to class (Cutshall et al., 2006); and even student profiles with respect to the implementation of a BYOD strategy on university campuses (Kobus et al, 2013).

Building on this last line, the objective of the present paper is to establish differentiated student profiles according to the type of electronic device that they are willing to take to class. The ultimate objective is for the findings to enable the optimized design and application of a BYOD strategy without the university having to bear the high costs of its implementation. The chosen case study is composed of a broad sample of students enrolled in the first cycle of the Business Management undergraduate degree course at the University of Seville (Spain). The study is also justified by the fact that the 
University of Seville cancelled a One-to-One Laptop program called "One student, One laptop" during the 2011-2012 academic year. Students were each loaned a laptop (to keep until the conclusion of their studies) in return for a deposit of 150 Euros. After the program was cancelled, a significant fall was seen in the number of laptops being used by students in the classroom.

The present study seeks to respond to questions about the real causes that explain this falling use of laptops from the perspective of an assessment given by the students themselves. The motives could include: the lack of financing for the purchase of a laptop (although free loan programs still exist for borrowing university-owned laptops by the hour); recent advances in technology that have broadened the range of possibilities of m-learning implementation in teaching (Valtonen et al., 2011); and using devices such as smartphones (O'Bannon and Bolton, 2014) and tablets (Kearney and Maher, 2013), whose purchase cost is generally lower than that of laptops. The present case study considers two devices for comparison, the laptop and the tablet, as these are the two pieces of electronic equipment most used for academic activities at the current time (Zayimand Ozel, 2015). The smartphone was excluded; as this is a device that the vast majority of students always carry around with them, generally for nonacademic reasons, analyzing any differences between the profiles of students who take smartphones to class and those who do not, would not be likely to contribute any relevant conclusions.

Based on a wide-ranging review of the prior literature on the BYOD strategy, four groups of determining factors are considered that affect the likelihood that a student might decide to take a tablet or a laptop to class (in the latter case, no distinction is made between a private device and one loaned by the university):

(1) The existence of any possible barriers to access, both to the ownership of mobile devices and to their usage, or to knowledge of the technology required for their usage (Holden \& Rada, 2011). These barriers are associated with personal and socioeconomic variables (Henriquez and Organista-Sandoval, 2012; Kearney et al, 2012; Moran et al., 2010;VibergandGrönbund, 2013; Zayinand Ozel, 2015;Zhang et al., 2014), and also with the student's academic record (Al-Emrhanet al., 2016; Jones et al., 2009).

(2) The possibility that usage of these devices could be distracting for the student (Alhassan, 2016; Fried, 2008; Ganand Blakrisshnan, 2014; Vazquez-Cano, 2015; Witeckiand Nonnecke, 2015; Chen \& Yan, 2016). All this has to be seen in the context of the spread of social networks, which are becoming increasingly used in a variety teaching experiments that analyze their use through electronic devices (Witecki and Nonnecke, 2015).Some examples are: Kassens (2014), Prestridge (2014)and Tur and Marín (2015) regarding the use of Twitter; Cuesta et al., (2016) and Sharma et al.(2016), for Facebook; studies that analyze both of these networks (Engel et al., 2014); and studies that examine the usage of the various social networks in economics classes 
(Al-Bahrani and Patel, 2015), or even the relationship between the usage of social networking sites and academic performance (Karpinski et al., 2013).

(3) Infrastructure and technical requirements to be able to securely use these devices "on the go" and have them permanently online during the whole of the academic day (Henríquez-Ritchie and Organista-Sandoval, 2012; Kobus et al., 2013; Pegrum et al., 2013; Sarrab et al., 2016).

(4) What students are demanding with respect to the implementation of these types of initiatives. This can range from demands for subsidies or programs for universities to loan out these devices (Kobus et al., 2013; Rockinson-Szapkiw et al., 2013) to a request for instructors to permanently integrate the use of these devices into their teaching activities with the proper adaptation of subject matter (Baran, 2014; Gikasand Grant, 2013; Zidney \& Warner, 2016).

Taking all these factors into consideration, the methodology chosen for this article is a bivariate probit model-based. This methodological focus has been selected with a view to obtaining more robust results than earlier, more descriptive studies (for example, Witecki and Nonnecke, 2015). It also enables the possibility to be considered -a very real possibility- that students could use one or other of the devices (laptop or tablet) interchangeably.

The study is divided into 4 sections. After the present introduction, Section 2 sets out the data and describes the methodology used for the analysis. Section 3 presents the model's results and their discussion. The last section sets out the conclusions.

\section{Data and methodology}

A broad database has been constructed for the study from a series of ad hoc survey campaigns. To be precise, each of the twelve groups taking the subjects "Introduction to Economics" (first year) and "Macroeconomics" (second year) on the Business Management undergraduate degree course at the University of Seville were surveyed. Although two different subjects, Introduction to Economics and Macroeconomics complement each other, as the first year teaching program includes an introduction to microeconomics and macroeconomics, with almost half the content linked to the second year subject. The online survey was conducted during the first term of the 2015-2016 academic year, with students accessing the questionnaire via a link posted on the subjects' virtual platform and responding using their own electronic devices.

The total size of the sample considered was 412 respondents. The key characteristics of the survey campaigns are listed in Table 1.

Table 1. Survey of technical data. 


\begin{tabular}{|c|c|c|}
\hline \multirow{2}{*}{$\begin{array}{l}\text { Information } \\
\text { gathering }\end{array}$} & $\begin{array}{l}\text { Questionnaire } \\
\text { format }\end{array}$ & Online questionnaire in Google Forms format \\
\hline & $\begin{array}{l}\text { Questionnaire } \\
\text { design }\end{array}$ & $\begin{array}{l}\text { Closed questionnaire with } 30 \text { questions: a combination of } \\
\text { open, multiple choice, yes/no and five point Likert scale-type } \\
\text { answers. }\end{array}$ \\
\hline \multirow[t]{3}{*}{ Sampling } & Universe & $\begin{array}{l}\text { Students enrolled in the } 12 \text { chosen groups who regularly attend } \\
\text { classes. }\end{array}$ \\
\hline & No. groups & \begin{tabular}{|l|l}
7 & 5 \\
\end{tabular} \\
\hline & Sample size & 151 \\
\hline \multirow{5}{*}{ Field work } & Place & Classrooms where the subject is taught \\
\hline & Time period & 16 - 22 November, 2015 \\
\hline & Timetable & Monday-Friday, in class time \\
\hline & Term & First term \\
\hline & $\begin{array}{l}\text { Academic } \\
\text { year }\end{array}$ & $2015-2016$ \\
\hline
\end{tabular}

A random sample method was used to collect the dataset. Given that the object of the survey was, precisely, the group of students enrolled on courses who regularly attended class, the campaign surveys on mobile device use were carried out without prior notice; during regular scheduled class time; during a normal academic period; on days with no approaching holiday/s; on days with no planned student meeting/s or test/s in other subjects, or any other unusual activity that might affect attendance.

For the survey to be conducted, students were only asked to take a wifi -enabled mobile device to class. No prior indication was given as to the day on which the survey would take place and no explanation was provided about what the intervention would entail. All the students used their devices in class to respond to the questionnaire via the link that had been duly posted on the virtual teaching platform.

The aim of the above was for the sample to approximate as closely as possible to the real total population and to prevent any changes in the behavior of students in the intervention group.

As explained above, the items selected for the survey were based on previous research (see Introduction Section). Students were asked about the types of electronic devices that they regularly took to class and a number of related questions that might influence this decision. These included socio-demographic factors and their levels of knowledge and use of new technologies and computer languages; their pre-university and university academic records; and the measures that they would consider appropriate to facilitate the use of laptops and tablets (as previously indicated, this study only distinguishes between the uses of these two types of devices in teaching). These questions were used to generate the 24 explanatory variables used in the model. Table 2 shows the full set of variables used in the model.

Table 2.Model variables

\begin{tabular}{l|l|l} 
NAME & DESCRIPTION & SCALE
\end{tabular}




\begin{tabular}{|c|c|c|}
\hline \multicolumn{3}{|c|}{ 1. Endogenous variables } \\
\hline Laptop & $\begin{array}{l}\text { Dummy variable to capture whether the } \\
\text { student takes a laptop to class or not }\end{array}$ & $\begin{array}{l}1 \text { if the student regularly takes a laptop } \\
\text { to class; } 0 \text { otherwise }\end{array}$ \\
\hline Tablet & $\begin{array}{l}\text { Dummy variable to capture whether the } \\
\text { student takes a tablet to class or not }\end{array}$ & $\begin{array}{l}1 \text { if the student regularly takes a tablet } \\
\text { to class; } 0 \text { otherwise }\end{array}$ \\
\hline \multicolumn{3}{|c|}{ 2. Explanatory variables } \\
\hline \multicolumn{3}{|c|}{ 2.1. Student's personal characteristics } \\
\hline Gender & Dummy variable for the student's gender & 1 if male; 0 if female \\
\hline Age & Age of person surveyed & Between 17 and 45 years \\
\hline Erasmus & $\begin{array}{l}\text { Dummy variable to capture whether the } \\
\text { student is a visiting foreign student on an } \\
\text { EU Erasmus program }\end{array}$ & $\begin{array}{l}1 \text { if a foreign student on an EU Erasmus } \\
\text { program; } 0 \text { otherwise }\end{array}$ \\
\hline Work & $\begin{array}{l}\text { Dummy variable to capture whether the } \\
\text { student has a job or not }\end{array}$ & $\begin{array}{c}1 \text { if the student combines his/her studies } \\
\text { with a paid job; } 0 \text { otherwise }\end{array}$ \\
\hline Family & $\begin{array}{l}\text { Dummy variable to capture the student's } \\
\text { family circumstances }\end{array}$ & $\begin{array}{l}1 \text { if the student has any dependent } \\
\text { family members; } 0 \text { otherwise. }\end{array}$ \\
\hline Home & $\begin{array}{c}\text { Dummy variable to capture where the } \\
\text { student lives }\end{array}$ & $\begin{array}{c}1 \text { if the student lives in the family } \\
\text { home; } 0 \text { otherwise (hall of residence or } \\
\text { student flat). }\end{array}$ \\
\hline Social Networks & $\begin{array}{l}\text { Number of social networks (Facebook, } \\
\text { Twitter, YouTube, Google+, Linked in } \\
\text { and Instagram) on which the student has } \\
\text { an account }\end{array}$ & Natural number: $1,2,3 \ldots$ \\
\hline Expertise & $\begin{array}{l}\text { Number of applications (Excel and } \\
\text { PowerPoint) or programming languages } \\
\text { (PHP and Javascript) that the student } \\
\text { knows how to use }\end{array}$ & Natural number: $1,2,3 \ldots$ \\
\hline Updating & $\begin{array}{l}\text { Discrete variable to express how often } \\
\text { the student updates his/her social } \\
\text { networks }\end{array}$ & $\begin{array}{l}0 \text { if does not update his/her profile or } \\
\text { does not belong to any social networks; } \\
1 \text { if updates less than once a month; } 2 \text { if } \\
\text { updates once a month; } 3 \text { if updates } \\
\text { every week; } 4 \text { if updates every day }\end{array}$ \\
\hline \multicolumn{3}{|c|}{ 2.2. Student's academic characteristics prior to university } \\
\hline $\begin{array}{l}\text { University admission } \\
\text { grade }\end{array}$ & $\begin{array}{l}\text { Grade with which the student gained } \\
\text { admission into university }\end{array}$ & Between 5.1and 13 \\
\hline High school & $\begin{array}{l}\text { Dummy variable to capture when the } \\
\text { student started university }\end{array}$ & $\begin{array}{c}1 \text { if the student started university } \\
\text { immediately after leaving high school; } \\
0 \text { otherwise }\end{array}$ \\
\hline Used before & $\begin{array}{l}\text { Dummy variable to capture whether the } \\
\text { student had used any electronic devices } \\
\text { in class before university }\end{array}$ & $\begin{array}{l}1 \text { if the student had regularly used } \\
\text { electronic devices in the classroom pre- } \\
\text { university; } 0 \text { otherwise }\end{array}$ \\
\hline \multicolumn{3}{|c|}{ 2.3. Classroom infrastructure and student's academic characteristics at university } \\
\hline Number Sockets & $\begin{array}{c}\text { Number of electrical sockets in the } \\
\text { classroom }\end{array}$ & Between 1 and 66 electrical sockets \\
\hline Shift & $\begin{array}{c}\text { Dummy variable to represent the } \\
\text { student's class shift }\end{array}$ & $\begin{array}{c}1 \text { morning class shift; } 0 \text { afternoon class } \\
\text { shift }\end{array}$ \\
\hline Year & $\begin{array}{l}\text { Dummy variable to represent year of the } \\
\text { student's degree course }\end{array}$ & $\begin{array}{l}2 \text { if the student is in the second year } \\
\text { (subject: Macroeconomics); } 1 \text { if the } \\
\text { student is in the first year (subject: } \\
\text { Introduction to Economics) }\end{array}$ \\
\hline Examinations & $\begin{array}{c}\text { Number of examination opportunities in } \\
\text { the subject }\end{array}$ & $\begin{array}{c}\text { Between } 1 \text { and 6examination } \\
\text { opportunities }\end{array}$ \\
\hline Attendance & $\begin{array}{c}\text { Number of subjects whose classes the } \\
\text { student attends regularly }\end{array}$ & Between 0 and 13 subjects \\
\hline Hours of home study & $\begin{array}{l}\text { Number of hours spent studying at home } \\
\text { per week }\end{array}$ & Between 0 and 24 hours \\
\hline \multicolumn{3}{|l|}{ 2.4. Student demands } \\
\hline Improvement_wifi & Degree to which the student considers & Likert scale: 1 . Strongly disagree; 2. \\
\hline
\end{tabular}




\begin{tabular}{|c|c|c|}
\hline & $\begin{array}{l}\text { the need for the University of Seville to } \\
\text { improve its wifi system }\end{array}$ & $\begin{array}{l}\text { Disagree; } 3 . \text { Neither agree nor disagree; } \\
\text { 4. Agree; } 5 \text {. Strongly agree }\end{array}$ \\
\hline Improvement_sockets & $\begin{array}{l}\text { Degree to which the student considers } \\
\text { the need for the university to increase the } \\
\text { number of electrical sockets in the } \\
\text { classrooms }\end{array}$ & $\begin{array}{c}\text { Likert scale: } 1 \text {. Strongly disagree; } 2 . \\
\text { Disagree; } 3 . \text { Neither agree nor disagree; } \\
\text { 4. Agree; } 5 \text {. Strongly agree }\end{array}$ \\
\hline Improvement_integration & $\begin{array}{l}\text { Degree to which the student considers } \\
\text { the need for instructors to better } \\
\text { integrate mobile device use into their } \\
\text { teaching }\end{array}$ & $\begin{array}{c}\text { Likert scale: } 1 \text {. Strongly disagree; } 2 . \\
\text { Disagree; } 3 . \text { Neither agree nor disagree; } \\
\text { 4. Agree; } 5 \text {. Strongly agree }\end{array}$ \\
\hline Improvement_loan & $\begin{array}{l}\text { Degree to which the student considers } \\
\text { the need for the university to prolong its } \\
\text { laptop loan period }\end{array}$ & $\begin{array}{c}\text { Likert scale: } 1 . \text { Strongly disagree; } 2 . \\
\text { Disagree; } 3 . \text { Neither agree nor disagree; } \\
\text { 4. Agree; } 5 \text {. Strongly agree }\end{array}$ \\
\hline Purchase_laptop & $\begin{array}{l}\text { Degree to which the student considers } \\
\text { the need for the university to subsidize } \\
\text { student purchase of computers }\end{array}$ & $\begin{array}{c}\text { Likert scale: } 1 . \text { Strongly disagree; } 2 . \\
\text { Disagree; } 3 . \text { Neither agree nor disagree; } \\
\text { 4. Agree; } 5 \text {. Strongly agree }\end{array}$ \\
\hline Purchase_tablet & $\begin{array}{l}\text { Degree to which the student considers } \\
\text { the need for the university to subsidize } \\
\text { student purchase of tablets }\end{array}$ & $\begin{array}{c}\text { Likert scale: } 1 \text {. Strongly disagree; } 2 . \\
\text { Disagree; } 3 . \text { Neither agree nor disagree; } \\
\text { 4. Agree; } 5 \text {. Strongly agree }\end{array}$ \\
\hline
\end{tabular}

A bivariate probit model was used to analyze the factors that affect students' decisions to take self-owned or University of Seville-loaned laptops to class and/or self-owned tablets. This model category is especially designed for cases where two non-exclusive questions with closely linked binary answers need to be answered (see Cameron and Trivedi, 2009 for a mathematical description of bivariate probits and Castillo Manzano et al., 2016for their application to education).

\section{Results and discussion}

Table 3 gives the descriptive statistics of the model variables presented in Table 2 .

Table 3.Variables: descriptive statistics.

\begin{tabular}{|l|c|c|c|c|}
\hline \multicolumn{1}{|c|}{ Variable } & No. Obs. = 1 & Mean & Median & Std. dev. \\
\hline 1. Endogenous variables & 73 & 0.178 & 0 & 0.383 \\
\hline Laptop & 64 & 0.156 & 0 & 0.364 \\
\hline Tablet & \multicolumn{5}{|l|}{} \\
\hline 2. Explanatory variables \\
\hline 2.1. Student's personal characteristics \\
\hline Gender & 203 & 0.496 & 0 & 0.501 \\
\hline Age & - & 19.531 & 19 & 2.746 \\
\hline Erasmus & 5 & 0.012 & 0 & 0.110 \\
\hline Work & 35 & 0.086 & 0 & 0.280 \\
\hline Family & 14 & 0.034 & 0 & 0.182 \\
\hline Home & 284 & 0.694 & 1 & 0.461 \\
\hline Social Networks & - & 3.457 & 3 & 1.220 \\
\hline Expertise & - & 1.951 & 2 & 0.712 \\
\hline Updating & - & 2.726 & 4 & 1.392 \\
\hline 2.2. Student's academic characteristics prior to university \\
\hline
\end{tabular}




\begin{tabular}{|l|c|c|c|c|}
\hline University admission grade & - & 9.166 & 9.075 & 1.476 \\
\hline High school & 379 & 0.927 & 1 & 0.261 \\
\hline Used before & 204 & 0.499 & 0 & 0.501 \\
\hline 2.3. Classroom infrastructure and student's academic characteristics at university \\
\hline Number Sockets & - & 9.477 & 4 & 18.983 \\
\hline Shift & 335 & 0.819 & 1 & 0.385 \\
\hline Year & - & 1.374 & 1 & 0.484 \\
\hline Examinations & - & 1.120 & 1 & 0.563 \\
\hline Attendance & - & 4.826 & 5 & 1.213 \\
\hline Hours of home study & - & 3.063 & 3 & 2.039 \\
\hline 2.4. Student demands & \multicolumn{4}{|l|}{} \\
\hline Improvement_wifi & - & 4.416 & 5 & 0.901 \\
\hline Improvement_sockets & - & 4.225 & 5 & 1.047 \\
\hline Improvement_integration & - & 3.597 & 4 & 1.140 \\
\hline Improvement_loan & - & 3.198 & 3 & 1.212 \\
\hline Purchase_laptop & - & 3.746 & 4 & 1.226 \\
\hline Purchase_tablet & - & 3.555 & 4 & 1.294 \\
\hline
\end{tabular}

Table 4 gives the results of the model. As in binary outcome models, only the mathematical sign of the coefficient can be interpreted directly in a bivariate probit model. Thus, a positive coefficient in the bivariate probit model means that, as the regressor increases, so there will be a greater likelihood that the event in question will occur, which in this case means that a student will be more likely to take a laptop and/or a tablet to the classroom. For this reason, the marginal effects of each of the explanatory variables have been calculated at the mean (see Table 4) to facilitate interpretation of the results.

Table 4. Marginal effects at the mean (as a percentage, \%) of the bivariate probit estimation.

\begin{tabular}{|l|c|c|}
\hline \multicolumn{1}{|c|}{ Variables } & Take laptop & Take tablet \\
\hline Gender & $\boldsymbol{\Delta} 2.201 \%(3.609)$ & $\boldsymbol{\nabla} 6.145 \%(2.053)^{* * *}$ \\
\hline Age & $\boldsymbol{\nabla} 0.099 \%(1.116)$ & $\boldsymbol{\nabla} 0.283 \%(0.559)$ \\
\hline Erasmus & $\boldsymbol{\Delta} 35.631 \%(36.221)$ & $\boldsymbol{\nabla} 5.253 \%(1.132)^{* * *}$ \\
\hline Work & $\boldsymbol{\nabla} 3.358 \%(5.688)$ & $\boldsymbol{\nabla} 3.225 \%(2.000)$ \\
\hline Family & $\boldsymbol{\nabla} 8.589 \% *(4.836)$ & $\boldsymbol{\Delta} 0.582 \%(5.455)$ \\
\hline Home & $\boldsymbol{\nabla} 7.169 \% *(4.092)$ & $\boldsymbol{\Delta} 4.835 \%(1.568)^{* * *}$ \\
\hline Social Networks & $\boldsymbol{\Delta} 1.304 \%(1.598)$ & $\boldsymbol{\Delta} 1.908 \%(0.801)^{* *}$ \\
\hline Expertise & $\boldsymbol{\nabla} 0.572 \%(2.472)$ & $\boldsymbol{\Delta} 1.101 \%(1.357)$ \\
\hline Updating & $\boldsymbol{\nabla} 2.042 \%(1.266)$ & $\Delta 0.280 \%(0.651)$ \\
\hline University admission grade & $\boldsymbol{\nabla} 1.855 \%(1.365)$ & $\boldsymbol{\Delta} 0.340 \%(0.661)$ \\
\hline
\end{tabular}




\begin{tabular}{|c|c|c|}
\hline High school & $\boldsymbol{\nabla} 11.232 \%(11.256)$ & $\Delta 9.498 \%(1.743)^{* * *}$ \\
\hline Used before & $\Delta 7.222 \% * *(3.618)$ & $\Delta 0.253 \%(1.801)$ \\
\hline Number sockets & $\Delta 0.4400 \% * * *(0.090)$ & $\Delta 0.106 \%(0.045) * *$ \\
\hline Shift & $\boldsymbol{\nabla} 4.038 \%(5.349)$ & $\boldsymbol{\nabla} 14.494 \%(5.732)^{* *}$ \\
\hline Year & $\Delta 11.157 \% * *(4.394)$ & $\Delta 3.604 \%(2.340)$ \\
\hline Examinations & $\Delta 2.704 \%(2.667)$ & $\Delta 2.018 \%(1.538)$ \\
\hline Attendance & $\boldsymbol{\nabla} 0.083 \%(1.489)$ & $\boldsymbol{\nabla} 1.737 \%(1.011)^{*}$ \\
\hline Hours of home study & $\Delta 0.670 \%(0.859)$ & $\nabla 1.161 \%(0.525)^{* *}$ \\
\hline Improvement_wifi & $\nabla 1.741 \%(2.354)$ & $\Delta 3.155 \%(1.413)^{* *}$ \\
\hline Improvement_sockets & $\Delta 9.432 \% * * *(2.307)$ & $\Delta 0.403 \%(1.308)$ \\
\hline Improvement_integration & $\Delta 3.973 \% * *(1.835)$ & $\Delta 1.988 \%(0.989)^{* *}$ \\
\hline Improvement_loan & $\nabla 3.641 \% * *(1.616)$ & $\boldsymbol{\nabla} 0.927 \%(0.852)$ \\
\hline Purchase_laptop & $\boldsymbol{\nabla} 5.482 \% * * *(1.894)$ & $\Delta 1.438 \%(1.017)$ \\
\hline Purchase_tablet & $\Delta 4.573 \% * *(1.833)$ & $\boldsymbol{\nabla} 0.223 \%(0.901)$ \\
\hline No. Observations & \multicolumn{2}{|c|}{387} \\
\hline Log pseudo likelihood & \multicolumn{2}{|c|}{-272.752} \\
\hline Wald chi2 test (p-value) & \multicolumn{2}{|c|}{$1560.33(0.000)$} \\
\hline Wald test of Rho=0 (p-value) & \multicolumn{2}{|c|}{$0.111(0.739)$} \\
\hline
\end{tabular}

Note: Standards errors in brackets robust to heteroscedasticity. One, two and three asterisks indicate coefficient significance at the 10 percent, 5 percent and 1 percent levels, respectively. $\Delta$ and $\nabla$ respectively indicate the increase or decrease in the likelihood that the student will take the analyzed mobile device to class.

The first result to be highlighted is that the hypothesis that Rho $=0$ (with Rho being the correlation between the error terms for the two analyzed decisions) is clearly not rejected. In fact, the Wald test of $\mathrm{Rho}=0$ gives a very high $\mathrm{p}$-value of above 0.7 . This implies that, contrary to what might be thought, laptop and tablet users in economics classes have very different profiles. From a methodological point of view, this means that separate probit estimations for the two outcomes (taking a laptop and/or a tablet to class) yield very similar coefficients to those obtained in Table $4^{1}$.

Analysis of the results also shows that only a minority of students take either a laptop or a tablet to class, $17.8 \%$ and $15.6 \%$, respectively. As some students are included in both categories, the real percentage of students taking one or other of the analyzed devices to class is only $29.8 \%$. Thus, this case study shows that the widespread integration of mobile devices into teaching in Spain is far from complete(2015), as although $51.7 \%$ of people over 15 years of age use laptops, this figure falls to $34.1 \%$ for tablets (ONTSI Spanish National Telecommunications Observatory, 2016).

In general terms, the results provide a clearer pattern of the demands of students who take mobile devices to class and as to how these demands vary according to the type of device used, than user profiles. However, it must also be stated that the model had

\footnotetext{
${ }^{1}$ Probit estimations are available from the authors upon request.
} 
greater success in defining the profile of tablet users more clearly than laptop users. The profiles for the two types of student are summarized in the following:

1. First, students that take laptops to university are characterized by usually living with their parents and not having any dependent family members (which indicates a major degree of self-sufficiency and independence). They are in favor of purchasing their own laptops (corroborating the results obtained by Zayimand Ozel, 2015) rather than receiving any public subsidies to purchase laptops or using the university loan system.

Considering differences by year, first year students who take their own laptops to class were already used to doing so during their pre-university period. Likewise, second year students have been observed to use self-owned laptops in class more than newcomers to university, which seems to indicate that the combination of the university's own dynamics and the students' greater degree of maturity leads to this type of device being taken to class (Moran et al., 2010).

The number of electrical sockets available for charging personal computers is also seen to be a factor that determines students' inclination to use laptops in class (Sarrab et al., 2016; Sobaih et al., 2016).

Lastly, students who take their laptops to class are seen to have some very specific different demands from other students. First, they make greater demands for the university to provide subsidies to help with the purchase of a tablet. And yet they give less support than other students to subsidies to purchase laptops and to the university increasing the number of hours that it loans laptops to its students for free.

2. Second, the profile of students who take tablets to university presents some clearly differentiated characteristics from those who take laptops. On the one hand, there are generally more females than males. This is in line with the Viberg and Grönlund (2013) study, which states that women adopt mobile technology for learning more quickly than men. However, other studies, such as Zayim and Ozel (2015), also exist which do not seem to find any gender-based differences.

The majority of students who take tablets to university also live at home with their parents, have arrived at university, for the most part, via the high school route, and attend classes on the afternoon shift. Also, these students have poorer attendance records and make greater use of social networks. Jointly these two characteristics would seem to indicate that tablets are linked to a greater tendency to be distracted. However, a range of studies (Alhassan, 2016; Fried, 2008; Witecki and Nonnecke, 2015) state that this is not an issue that is exclusive to tablet users, and that it is also true of laptop users. Notwithstanding, there is also other research that states that tablet use has a positive effect on attendance, achievement and progression (Wilkinson and Barter, 2016). 
With respect to the question of infrastructure and technical requirements, unlike students who take their laptops to class, those who take their tablets do not demand a greater number of electrical sockets to recharge their batteries, but an improved wifi system, i.e., they are more interested in a better broadband connection than an improved charging capability (Pegrum et al., 2013; Zayim and Ozel, 2015). This demand for a better internet connection could be related to the previously stated greater use that these students make of social networks and leisure and entertainment applications, as these require a high quality connection.

However, it could also be due to the fact that medium-to-low cost tablets are equipped with cheaper -and, therefore, poorer quality- modems than laptops, which would also mean that they require better quality wifi.

Two characteristics common to both profiles can be highlighted. First, both types of student demand that instructors further integrate the use of these electronic devices into their regular teaching activity (Baran, 2014; Gikas and Grant, 2013; Zidney, \& Warner, 2016). This demand is in contention with a number of constraints, such as some instructors lacking due technical training (Cochrane, 2014; Peng, Su, Chou, and Tsai, 2009) and there is even reticence to use new technologies on the part of some instructors, possibly linked to the not always well-founded aura of prestige that surrounds the traditional lecture class given by an instructor, especially at higher teaching levels (Vázquez-Cano, 2015; Yoiro and Feifei, 2012).

Lastly, it is important to highlight the lack of significance of the variables that measure expert IT knowledge and university admission grade in both profiles. This would indicate that in this case there are no barriers to entry, either technical or intellectual, for university students. In other words, per se, any and every university student would possess the minimum knowledge required to use a tablet or laptop effectively in class (as suggested by Chen \& Yan, 2016 and Holden and Rada, 2011).

\section{Conclusions}

Nowadays, so-called m-learning, or technology-based teaching methodology, has spread all round the world, especially in university teaching, as it enables university students to learn through collaborative idea-sharing and affords closer interaction with the instructor. Most studies reflect the great acceptance that technology has had among students regarded as "digital natives" and their readiness to use it in the learning process. However, as well as this shared behavior, there are personal, socio-economic and technical differences that explain students' preferences for the use of one device or another.

More specifically, using fieldwork consisting of an extensive survey campaign of students on the Business Management undergraduate degree course at the University of 
Seville, the present article compares the profiles of two groups of students: those who use laptops in class, and those who use tablets. The findings, obtained through the application of a discrete choice model, namely a bivariate probit model, show that tablet users' characteristics are more clearly profiled than laptop users'.

To be precise, users who prefer to take laptops to class usually live with their parents, have already used laptops in their pre-university studies, and are concerned about the possibility of charging their batteries in class. In contrast, users who take their tablets to class also usually live with their parents, are very active on social networks, and more concerned about the quality of the internet connection than about recharging their devices.

These results imply that the policy to promote m-learning should begin with the university itself, with improvements made to both physical infrastructure, through the installation of more electrical sockets in classrooms, and to ICTs, with better wifi networks. However, evident correlation between the use of social networks and the presence of tablets in class is a clear warning that discussion is needed about the possibility of restricting access to internet leisure content over the university wifi network, at least during class time.

In addition, both groups of students demand that instructors further integrate the use of these devices into their teaching activities. To put it another way, what they are seeking is a greater academic return on the personal investment that they make when they purchase and/or borrow the device, in the case of the laptop, and on the personal cost of having to carry the device around all day. Therefore, following the study by Al-Emran et al. (2016), one future line of research could focus on analyzing the profile of the instructor who uses m-learning in the university environment. The result of such a study would help define a number of recommendations that would further engage university instructors in m-learning and respond to the above-mentioned student demand. Naturally, it would also be useful to replicate this study at other, preferably non-Spanish universities to discover how widespread the obtained conclusions are or, to put it another way, whether they can be extrapolated to other university environments.

\section{References}

Al-Bahrani, A., and Patel, D. (2015). Incorporating twitter, instagram, and facebook in economics classrooms. The Journal of Economic Education, 46(1), 56-67.

Al-Emran, M., Elsherif, H. M., and Shaalan, K. (2016). Investigating attitudes towards the use of mobile learning in higher education. Computers in Human Behavior, 56, 93102. 
Alhassan, R. (2016). Mobile Learning as a Method of Ubiquitous Learning: Students' Attitudes, Readiness, and Possible Barriers to Implementation in Higher Education. Journal of Education and Learning, 5(1), 176-189.

Althunibat, A. (2015). Determining the factors influencing students' intention to use mlearning in Jordan higher education. Computers in Human Behavior, 52, 65-71.

Baran, E. (2014). A Review of Research on Mobile Learning in Teacher Education. Educational Technology and Society, 17(4), 17-32.

Castillo-Manzano, J.I., Castro-Nuño, M., Sanz, T. and Yñiguez, R. (2016). Does pressing a button make it easier to pass an exam? Evaluating the effectiveness of interactive technologies in higher education. British Journal of Educational Technology, 47 (4), 710-720.

Chen, Q., and Yan, Z. (2016). Does multitasking with mobile phones affect learning? A review. Computers in Human Behavior, 54, 34-42.

Cheung, S. L. (2008). Using mobile phone messaging as a response medium in classroom experiments. The Journal of Economic Education, 39(1), 51-67.

Cochrane, T. D. (2014). Critical success factors for transforming pedagogy with mobile Web 2.0. British Journal of Educational Technology, 45(1), 65-82.

Cook, J., and Santos, P. (2016). Three Phases of Mobile Learning State of the Art and Case of Mobile Help Seeking Tool for the Health Care Sector. In Mobile Learning Design (pp. 315-333). Springer, Singapore.

Crompton, H., Burke, D., Gregory, K. H., and Gräbe, C. (2016). The Use of Mobile Learning in Science: A Systematic Review. Journal of Science Education and Technology, 25(2), 149-160.

Cuesta, M., Eklund, M., Rydin, I., and Witt, A. K. (2016). Using Facebook as a colearning community in higher education. Learning, Media and Technology, 41(1), 5572.

Cutshall, R., Changchit, C., and Elwood, S. (2006). Campus laptops: What logistical and technological factors are perceived critical?. Educational Technology and Society, 9(3), 112-121.

Domingo, M. G., and Garganté, A. B. (2016).Exploring the use of educational technology in primary education: Teachers' perception of mobile technology learning impacts and applications' use in the classroom. Computers in Human Behavior, 56, 2128. 
Engel, R., Murphy, P. R., and Fisk, C. (2014). Economics Memes: How to use Memes to Teach and Learn Economics. The Journal of Economic Education, 45(1), 75-76.

Fisher, M., and Baird, D. (2006). Making m-learning work: Utilizing mobile technology for active exploration, collaboration, assessment, and reflection in higher education. Journal of Educational Technology Systems, 35(1), 3-30.

Fried, C. B. (2008). In-class laptop use and its effects on student learning. Computers and education, 50(3), $906-914$.

Gan, C. L., and Balakrishnan, V. (2014). Determinants of mobile wireless technology for promoting interactivity in lecture sessions: an empirical analysis. Journal of Computing in Higher Education, 26(2), 159-181.

Gikas, J., and Grant, M. M. (2013). Mobile computing devices in higher education: Student perspectives on learning with cellphones, smartphones \& social media. The Internet and Higher Education, 19, 18-26.

Green, A. (2016). Significant returns in engagement and performance with a free teaching app. The Journal of Economic Education, 47(1), 1-10.

Hassan, I. M., Khan, H. U., and Lalitha, V. M. (2016). Pedagogical potentials of IEEE 802.11 WLAN to Nigerian universities: a case study of the University of Uyo. International Journal of Information and Education Technology, 6(4), 256-261.

Holden, H., and Rada, R. (2011). Understanding the influence of perceived usability and technology self-efficacy on teachers' technology acceptance. Journal of Research on Technology in Education, 43(4), 343-367.

Holderied, A. C. (2016). Instructional design for the active: Employing interactive technologies and active learning exercises to enhance information literacy in Information and Data Literacy: The Role of the Library, (pp.111-125). Apple Academic Press. Oakville.

Henríquez-Ritchie, P., and Organista-Sandoval, J. (2012). Propuesta metodológica para la caracterización de actividades de m-learning realizadas por estudiantes de una universidad pública. Revista Iberoamericana para la Investigación y el Desarrollo Educativo. (8: January-June). Accesible at: http://www.ride.org.mx/111/index.php/RIDESECUNDARIO/article/download/39/39.

Holden, H., \& Rada, R. (2011). Understanding the influence of perceived usability and technology self-efficacy on teachers' technology acceptance. Journal of Research on Technology in Education, 43(4), 343-367. 
Howard, S. K., Chan, A., Mozejko, A., and Caputi, P. (2015). Technology practices: Confirmatory factor analysis and exploration of teachers' technology integration in subject areas. Computers and Education, 90, 24-35.

Husbye, N. E., and Elsener, A. A. (2013). To move forward, we must be mobile: Practical uses of mobile technology in literacy education courses. Journal of Digital Learning in Teacher Education, 30(2), 46-51.

Hwang, G. J., and Wu, P. H. (2014). Applications, impacts and trends of mobile technology-enhanced learning: a review of 2008-2012 publications in selected SSCI journals. International Journal of Mobile Learning and Organisation, 8(2), 83-95.

Imazeki, J. (2014). Bring-your-own-device: Turning cell phones into forces for good. The Journal of Economic Education, 45(3), 240-250.

Jacob, S. M., and Issac, B. (2008). The mobile devices and its mobile learning usage analysis. Proceedings of the International MultiConference of Engineers and Computer Scientists 2008 Vol I IMECS 2008, 19-21 March, 2008, Hong Kong. Accesible at: https://arxiv.org/ftp/arxiv/papers/1410/1410.4375.pdf.

James, J. (2015). Macroeconomic consequences of the one laptop per child project. Journal of International Development, 27(1), 144-146.

Jemni, M., Khribi, K., Othman, A., Elghoul, O., and Jaballah, K. (2016). AlecsoApps: Toward Empowering Mobile Applications Development in the Arab World. In State-ofthe-Art and Future Directions of Smart Learning (pp. 87-93). Springer, Singapore.

Jones, G., Edwards, G., and Reid, A. (2009). How Can Mobile SMS Communication Support and Enhance a First Year Undergraduate Learning Environment? ALT-J: Research in Learning Technology, 17(3), 201-218.

Jordano de la Torre, M., de Larreta-Azelain, C., Dolores, M., and Pareja Lora, A. (2016). El aprendizaje de lenguas extranjeras mediante tecnología móvil en el contexto de la educación a distancia y combinada. RIED: Revista Iberoamericana de Educación a Distancia, 19(1), 25-40.

Karpinski, A. C., Kirschner, P. A., Ozer, I., Mellott, J. A., and Ochwo, P. (2013). An exploration of social networking site use, multitasking, and academic performance among United States and European university students. Computers in Human Behavior, 29(3), 1182-1192.

Kassens, A. L. (2014). Tweeting your way to improved\# Writing, \# Reflection, and\# Community. The Journal of Economic Education, 45(2), 101-109. 
Kearney, M., and Maher, D. (2013). Mobile learning in math teacher education: Using iPads to support pre-service teachers' professional development. Australian Educational Computing, 27(3), 76-84.

Kearney, M., Schuck, S., Burden, K., and Aubusson, P. (2012). Viewing mobile learning from a pedagogical perspective. Research in learning technology, 20, 1-17.

Kim, D. K., Jeong, D., Lu, L., Debnath, D., and Ming, H. (2016). Opinions on computing education in Korean K-12 system: higher education perspective. Computer Science Education, 25(4), 371-389.

Kobus, M. B., Rietveld, P., and Van Ommeren, J. N. (2013). Ownership versus oncampus use of mobile IT devices by university students. Computers and Education, 68, $29-41$.

Kong, S. C., and Song, Y. (2015). An experience of personalized learning hub initiative embedding BYOD for reflective engagement in higher education. Computers and Education, 88, 227-240.

Landers, R. N., and Armstrong, M. B. (2015). Enhancing instructional outcomes with gamification: An empirical test of the Technology-Enhanced Training Effectiveness Model. Computers in Human Behavior. In press, DOI: 10.1016/j.chb.2015.07.031.

Lin, Y. T., and Lin, Y. C. (2016). Effects of mental process integrated nursing training using mobile device on students' cognitive load, learning attitudes, acceptance, and achievements. Computers in Human Behavior, 55, 1213-1221.

Lin, H. H., Wang, Y. S., and Li, C. R. (2016). Assessing Mobile Learning Systems Success. International Journal of Information and Education Technology, 6(7), 576.

McEwen, R. N., and Dubé, A. K. (2015). Engaging or Distracting: Children's Tablet Computer Use in Education. Journal of Educational Technology and Society, 18(4), 923.

Moran, M., Hawkes, M., and El Gayar, O. (2010). Tablet personal computer integration in higher education: Applying the unified theory of acceptance and use technology model to understand supporting factors. Journal of Educational Computing Research, 42(1), 79-101.

Mosleh, M. A., Baba, M. S., Malek, S., and Alhussein, M. A. (2016). Challenges of Digital Note Taking. In Advanced Computer and Communication Engineering Technology (pp. 211-231). Springer International Publishing. 
Nielsen, W., Miller, K. A., and Hoban, G. (2015).Science Teachers' Response to the Digital Education Revolution. Journal of Science Education and Technology, 24(4), 417-431.

Norman, E., and Furnes, B. (2016). The relationship between metacognitive experiences and learning: Is there a difference between digital and non-digital study media?. Computers in Human Behavior, 54, 301-309.

O'Bannon, B. W., and Thomas, K. (2014). Teacher perceptions of using mobile phones in the classroom: Age matters. Computers and Education, 74, 15-25.

ONTSI (2016). Las TIC en los hogares españoles. Estudio de demanda y uso de Servicios de Telecomunicaciones y Sociedad de la Información. Observatorio Nacional de las Telecomunicaciones y de la SI, julio - septiembre 2015. Ministerio de Industria, Madrid.

Pegrum, M., Howitt, C., and Striepe, M. (2013).Learning to take the tablet: How preservice teachers use iPads to facilitate their learning. Australasian Journal of Educational Technology, 29(4), 464-479.

Peng, H., Su, Y. J., Chou, C., \& Tsai, C. C. (2009). Ubiquitous knowledge construction: Mobile learning re-defined and a conceptual framework. Innovations in Education and Teaching International, 46(2), 171-183.

Peña-Ayala, A., \& Cárdenas, L. (2016). A Revision of the Literature Concerned with Mobile, Ubiquitous, and Pervasive Learning: A Survey. In Mobile, Ubiquitous, and Pervasive Learning (pp. 55-100). Springer International Publishing.

Pereira, S., and Pereira, L. (2015). Digital Media in Primary Schools: Literacy or Technology? Analyzing Government and Media Discourses. Educational Policy, 29 (6), 316-341.

Peters, K. (2007). M-Learning: Positioning educators for a mobile, connected future. The International Review of Research in Open and Distributed Learning, 8(2). http://www.irrodl.org/index.php/irrodl/article/view/350/914

Prestridge, S. (2014). A focus on students' use of Twitter-their interactions with each other, content and interface. Active Learning in Higher Education, 15(2), 101-115.

Popović, O., Marković, D. S., and Popović, R. (2016). mTester-Mobile learning system. Computer Applications in Engineering Education, 24, 412-420. 
Reychav, I., and Wu, D. (2015). Mobile collaborative learning: the role of individual learning in groups through text and video content delivery in tablets. Computers in Human Behavior, 50, 520-534.

Redd, J. (2011). Supporting vocabulary growth of high school students: An analysis of the potential of a mobile learning device and gaming app. Graduate Theses and Dissertations. Paper 12079. Iowa State University. Accesible at: http://lib.dr.iastate.edu/etd/12079.

Reychav, I., \& Wu, D. (2015). Mobile collaborative learning: the role of individual learning in groups through text and video content delivery in tablets. Computers in Human Behavior, 50, 520-534.

Rockinson-Szapkiw, A. J., Courduff, J., Carter, K., and Bennett, D. (2013). Electronic versus traditional print textbooks: A comparison study on the influence of university students' learning. Computers and Education, 63, 259-266.

Sarrab, M., Elbasir, M., and Alnaeli, S. (2016). Towards a quality model of technical aspects for mobile learning services: An empirical investigation. Computers in Human Behavior, 55, 100-112.

Sharma, S. K., Joshi, A., and Sharma, H. (2016). A multi-analytical approach to predict the Facebook usage in higher education. Computers in Human Behavior, 55, 340-353.

Shuib, L., Shamshirband, S., and Ismail, M. H. (2015). A review of mobile pervasive learning: Applications and issues. Computers in Human Behavior, 46, 239-244.

Sobaih, A. E. E., Moustafa, M. A., Ghandforoush, P., and Khan, M. (2016). To use or not to use? Social media in higher education in developing countries. Computers in Human Behavior, 58, 296-305.

Song, Y. (2014). "Bring Your Own Device (BYOD)" for seamless science inquiry in a primary school. Computers and Education, 74, 50-60.

Song, Y. (2016). "We found the 'black spots' on campus on our own": development of inquiry skills in primary science learning with BYOD (Bring Your Own Device). Interactive Learning Environments, 24(2), 291-305.

Tur, G., and Marín, V. I. (2015). Enhancing learning with the social media: student teachers' perceptions on Twitter in a debate activity. Journal of New Approaches in Educational Research, 4(1), 46-59. 
Valk, J.-H., Rashid, A., and Elder, L. (2010). Using Mobile Phones to Improve Educational Outcomes: An Analysis of Evidence from Asia. International Review of Research in Open and Distance Learning, 11 (1), 117-140.

Valtonen, T., Havu-Nuutinen, S., Dillon, P., and Vesisenaho, M. (2011). Facilitating collaboration in lecture-based learning through shared notes using wireless technologies. Journal of Computer Assisted Learning, 27(6), 575-586.

Vázquez-Cano, E. (2015). El reto de la formación docente para el uso de dispositivos digitales móviles en la educación superior. Perspectiva Educacional, 54(1), 149-162.

Viberg, O., and Grönlund, Å. (2013). Cross-cultural analysis of users' attitudes toward the use of mobile devices in second and foreign language learning in higher education: A case from Sweden and China. Computers and Education, 69, 169-180.

Wang, A. I. (2015). The wear out effect of a game-based student response system. Computers and Education, 82, 217-227.

Wilkinson, K., and Barter, P. (2016). Do mobile learning devices enhance learning in higher education anatomy classrooms? Journal of Pedagogic Development, 6(1), 14-23.

Witecki, G., and Nonnecke, B. (2015). Engagement in Digital Lecture Halls: A Study of Student Course Engagement and Mobile Device use During Lecture. Journal of Information Technology Education: Research, 14, 73-90.

Wong, H. H. H., and Mak, K. K. W. (2016). Method and system for classroom active learning. U.S. Patent No. 9,240,127. Washington, DC: U.S. Patent and Trademark Office.

Wu, J. H., Tennyson, R. D., Hsia, T. L., and Liao, Y. W. (2008). Analysis of E-learning innovation and core capability using a hypercube model. Computers in Human Behavior, 24(5), 1851-1866.

Wu, J. H., Tennyson, R. D., and Hsia, T. L. (2010). A study of student satisfaction in a blended e-learning system environment. Computers \& Education, 55(1), 155-164.

Wu, W. H., Wu, Y. C. J., Chen, C. Y., Kao, H. Y., Lin, C. H., and Huang, S. H. (2012). Review of trends from mobile learning studies: A meta-analysis. Computers and Education, 59(2), 817-827.

Yoiro, P and Feifei, Y. (2012). A Meta -Analysis on the Effects of Service Learning on the Social, Personal, and Cognitive Outcomes of Learning .Learning \& Education, 11, 9 -27 . 
Zahadat, N., Blessner, P., Blackburn, T., and Olson, B. A. (2015). BYOD security engineering: A framework and its analysis. Computers and Security, 55, 81-99.

Zhang, Xi., Ordóñez de Pablos, P., and Xu, Q. (2014). Culture effects on the knowledge sharing in multi-national virtual classes: A mixed method. Computers in Human Behavior, 31, 491-498.

Zayim, N., and Ozel, D. (2015). Factors Affecting Nursing Students' Readiness and Perceptions Toward the Use of Mobile Technologies for Learning. Computers Informatics Nursing, 33(10), 456-464.

Zidney, J and Warner, Z. (2016). Mobile apps for science learning: Review of research. Computers and Education, 94, 1-17. 